\title{
Bioefficacy of Some Aqueous Phytoextracts Against Clavibacter Michiganensis Subsp. Michiganensis (Smith), the Cause of Bacterial Canker of Tomato
}

\author{
Muhammad Siddique ${ }^{1} \cdot$ Naseerud Din ${ }^{1} \cdot$ Musharaf Ahmad ${ }^{1} \cdot$ Asad Ali ${ }^{1}$ Ishrat Naz ${ }^{1}$ Syed Sartaj Alam ${ }^{1}$. \\ Najeeb Ullah ${ }^{2}$
}

Received: 29 February 2020 / Accepted: 16 April 2020 / Published online: 7 May 2020

(c) The Author(s) 2020

\begin{abstract}
The ability of some medicinal plants was explored to control bacterial canker of tomato caused by Clavibacter michiganensis subsp. michiganensis. The plants tested included Peganum harmala, Allium sativum, Withania somnifera, Melia azedarach, Calotropis procera, Mentha piperita and Nerium oleander. Aqueous extracts of $P$. harmala and M. piperita proved to be very effective under in vitro conditions against Clavibacter michiganensis subsp. michiganensis. In in vivo studies, the highest dose of dried powder of $P$. harmala and $M$. piperita $\mathrm{kg}^{-1}$ of soil decreased disease severity significantly. Other yield-contributing parameters were also enhanced by the application of dried powder and no phytotoxicity was observed at given concentrations. Alkaloids, tannins, glycosides, flavonoids and saponins were detected in aqueous extracts of P. harmala, W. somnifera, M. azedarach, C. procera and M. piperita. Dried powders of P. harmala and M. piperita could be incorporated as an integral part in the integrated disease management programs against Clavibacter michiganensis subsp. michiganensis.
\end{abstract}

Keywords Clavibacter michiganensis subsp. michiganensis $\cdot$ Peganum harmala $\cdot$ Calotropis procera $\cdot$ Withania somnifera $\cdot$ Melia azedarach $\cdot$ Mentha piperita

\section{Biologische Wirksamkeit einiger wässriger Phytoextrakte gegen Clavibacter michiganensis subsp. michiganensis (Smith), dem Auslöser des bakteriellen Krebses bei Tomaten}

\section{Zusammenfassung}

Die Studie untersuchte die Eignung einiger Arzneipflanzen zur Bekämpfung des bakteriellen Krebses bei Tomaten, der durch Clavibacter michiganensis subsp. michiganensis verursacht wird. Zu den getesteten Pflanzen gehörten Peganum harmala, Allium sativum, Withania somnifera, Melia azedarach, Calotropis procera, Mentha piperita und Nerium oleander. Wässrige Extrakte von $P$. harmala und M. piperita erwiesen sich unter in-vitro-Bedingungen als sehr wirksam gegen Clavibacter michiganensis subsp. michiganensis. In in-vivo-Studien verringerte die höchste Dosis an getrocknetem Pulver von P. harmala und M. piperita die Krankheitsschwere signifikant. Auch andere ertragsfördernde Parameter wurden durch die Anwendung von getrocknetem Pulver verbessert, und bei den vorliegenden Konzentrationen wurde keine Phytotoxizität beobachtet. Alkaloide, Tannine, Glykoside, Flavonoide und Saponine wurden in den wässrigen Extrakten von $P$. harmala, $W$. somnifera, $M$. azedarach, $C$. procera und $M$. piperita nachgewiesen. Die getrockneten Pulver von $P$. harmala und M. piperita könnten als wichtiger Bestandteil in die integrierten Disease-Management-Programme gegen Clavibacter michiganensis subsp. michiganensis aufgenommen werden.

Schlüsselwörter Clavibacter michiganensis subsp. michiganensis · Peganum harmala $\cdot$ Calotropis procera $\cdot$ Withania somnifera $\cdot$ Melia azedarach $\cdot$ Mentha piperita

Naseerud Din

naseerppl@aup.edu.pk
1 Department of Plant Pathology, University of Agriculture, P.O. Box. 25130, Peshawar, Khyber Pakhtunkhwa, Pakistan

2 Nuclear Institute for Agriculture and Biology (NIAB), Faisalabad, Pakistan 


\section{Introduction}

Tomato (Lycopersicon esculentum Mill.), a member of Solanaceae, is an important vegetable crop of Pakistan. The area under tomato cultivation in Pakistan is 40,238 hectares, with a total production of 566,043 tons while Khyber Pakhtunkhwa (KPK) province of Pakistan contributes an area of over 13,252 hectares with a production of 127,552 tons (Anonymous 2016). Cultivation of tomato crop has sharply increased in the country due to its growing demand. However, the demand-supply situation is still imbalanced mainly due to production constrains. Plant diseases, caused by fungi, viruses, nematodes and bacteria, are one of the major factors limiting tomato production (Agrios 2005). Among bacterial diseases, bacterial canker, caused by Clavibacter michiganensis subsp. michiganensis (Smith), is a potentially severe disease of tomato that can occur in commercial plantings and home gardens. This infectious disease is capable of spreading rapidly resulting in devastating losses. Bacterial canker has caused huge economic losses in commercial tomato production throughout the world (Davis et al. 1984). The bacterium is aerobic, Gram-positive, non-motile, non-spore forming, curved rod (Bradbury 1986). The pathogen is seed-borne as well as plant-debris borne (Dutta et al. 2014).

Bacterial canker produces dark, necrotic lesions at the edges of older leaves. On the surface of young leaves and fruits, the bacteria multiply rapidly and produce tiny, raised, white blisters. Later, the centers of the white blisters turn brown, giving rise to "bird's-eye" spots which is the characteristic symptom of bacterial canker. The vascular tissues of transversely cut stems of wilted plants near the nodes usually appear dark yellow to tan brown. On seedlings, initially, small, water-soaked lesions appear on stems and leaves which later turn into necrotic patches leading to stunting and wilting. On green-house-grown tomato plants, symptoms appear as chlorotic patches between veins that quickly become necrotic. On infected stems, light brown streaks or cankers appear which turn dark with the age. In many cases, plants affected by bacterial canker wilt and die (Bose et al. 2004). Warm temperatures $\left(29-35^{\circ} \mathrm{C}\right)$ and high relative humidity favor the disease (Shenge et al. 2010).

The best disease control strategy to manage a hard-tocontrol disease, like bacterial canker, is the use of integrated disease management (IDM). Various components of IDM could include the use of resistant cultivars, pathogen-free seeds and transplants, green house disinfection, removal of infected plant debris, proper sanitation and rotation with non solanaceous plants for at least two years etc. (Gleason et al. 1993; Pradhanang et al. 2005). However, because of the complex nature of the pathogen, many of these strategies are of limited use (Hong et al. 2011). The scarcity of effective control measures and the magnitude of bacterial canker on economical crops, necessitate the search for new control options. One of such options is the use of dried powders or extracts of medicinal plants/weeds. A number of plants/ weeds have been reported (Singariya et al. 2011; Singh and Kumar 2014; Bokaeian and Saeidi 2015) to have strong antibacterial properties. These plants have secondary metabolites, such as alkaloids, flavonoids, steroids, glycosides, saponins, and tannins, which possess antimicrobial properties (Cowan 1999). The goal of this study was to explore the bacterial-canker-control potential of those medicinal plants/ weeds which have a long history as folk medicines and which are easily available in large amounts year round. We evaluated seven such medicinal plants/weeds including Withania somnifera, Melia azedarach, Peganum harmala, Allium sativum, Calotropis procera, Nerium oleander and Mentha piperita for their ability to inhibit the in vitro growth of the tomato canker bacterium using aqueous plant extracts and agar well diffusion method as well as the ability of some of these plants to reduce disease severity and enhance plant parameters in vivo.

Keeping in view the ever-increasing demand and the economic importance of tomatoes in Pakistan, the potential threat of bacterial canker to profitable tomato crop, the lack of our resource-poor farmers to afford the high costs of disease control inputs, the possible effectiveness and the year round, free of cost, large-scale availability of these medicinal plants, we tested the potential of these for the control of bacterial canker of tomato. Both in vitro and in planta experiments were carried out. The hypothesis was that the aqueous extracts of some of these medicinal plants would be inhibitory to the in vitro growth of the bacterial canker pathogen and this inhibitory effect would be equally effective for the control of the disease on tomato plants grown under screen house conditions. Moreover, we hoped that the in vivo use of the dried powders of some of these medicinal plants, if found effective, would be very economical for our small land-holding farmers on one hand, and would eliminate or at least reduce the environment-polluting chemicals such as antibiotics or copper fungicides used to control plant bacterial diseases, on the other hand. In addition to being environment-friendly, the use of dried powder soil amendments will also deter the appearance of chemical-resistant bacteria (Cowan 1999) as well as enhance tomato yield by controlling the disease and improving the physical and chemical properties of soil. The objectives of this study were (i) to investigate the potential of the aqueous extracts of these selected plants to inhibit the in vitro growth of the tomato canker pathogen, and (ii) to correlate the in vitro bacterial growth inhibition to in planta disease control and plant growth parameters enhancement. 


\section{Materials and Methods}

\section{Bacterial Culture and Inoculum Preparation}

Clavibacter michiganensis subsp. michiganensis (Cmm) was obtained from plant bacterial culture bank of the Department of Plant Pathology, the University of Agriculture (UOA), Peshawar. The bacterium was sub-cultured on nutrient agar (NA) medium (per 1 L: beef extract, $3 \mathrm{~g}$; peptone, $5 \mathrm{~g}$; agar, $15 \mathrm{~g}$ ) and incubated overnight at $28^{\circ} \mathrm{C}$. To confirm the purity of the culture, its morphological characteristics such as colony color, colony shapes, margins, and elevation were carefully observed. The bacterial growth was dislodged off the surface of each plate by adding a small amount of sterilized distilled water (SDW) to each plate and carefully scrapping the surface with a rubber spatula. Bacterial suspension was adjusted to $10^{8} \mathrm{cfu} / \mathrm{ml}$ with the help of spectrophotometer, $\mathrm{OD}_{600}=0.5-0.7$ (Xiulan et al. 2010). This suspension was used for in vitro bacterial growth inhibition tests, pathogenicity tests and for inoculation of healthy plants during the in planta experiments.

\section{Pathogenicity Tests}

Pathogenicity of the bacterium was confirmed by injecting the bacterial suspension $\left(10^{8} \mathrm{cfu} / \mathrm{ml}, \mathrm{OD}_{600}=0.5-0.7\right)$ (Xiulan et al. 2010) into stems of four-week old tomato plants, variety Rio Grande (Din et al. 2016). Control plants were injected with sterile distilled water. The seedlings were placed in humid chamber (average $\mathrm{RH}=80 \%$, temperature, $25-30^{\circ} \mathrm{C}$, dim light for $12 \mathrm{~h}$ daily) for up to four weeks. The plants were evaluated regularly for the appearance of bacterial canker disease symptoms. The bacterium was re-isolated from the infected portion of plants in sterile distilled water and was cultured on nutrient agar medium (Kleitman et al. 2009).

\section{Medicinal Plants and Extracts Preparation}

Green leaves and succulent branches of the seven medicinal plants/weeds (30-60 plants per species) viz W. somnifera, $M$. azedarach, $P$. harmala, A. sativum, C. procera, $N$. oleander and M. piperita were collected from different regions of Peshawar and Darra Adam Khel, F.R Kohat, Khyber Pakhtunkhwa province of Pakistan, authenticated by a weed botanist of the Department of Weed Science, UOA, Peshawar, Pakistan and specimen were deposited in the university herbarium. The plant materials of each species were separately pooled together, washed under tap water, cut into small pieces and then shade-dried for about six weeks. The brittle-dried cut-pieces of each plant species separately ground to make very fine powder ( $2 \mathrm{~mm}$ mesh) (Kumar et al. 2011). The powders of all plant species were separately stored at $4^{\circ} \mathrm{C}$ in air tight plastic containers (Oguike et al. 2013). In order to prepare aqueous extracts, $10 \mathrm{~g}$ powder $(10 \% \mathrm{w} / \mathrm{v})$ of each plant species was separately mixed with sterilized distilled water (SDW) and the volume was adjusted to $100 \mathrm{ml}$ (Frey and Mayers 2010). The suspension of each plant species was soaked for $48 \mathrm{~h}$, and filtered through Whatman filter $(20 \mu \mathrm{m})$. The solid material was discarded; the filtrate was saved and used for making different dilutions $(75 \%, 50 \%$, and $25 \%)$.

\section{In Vitro Studies}

To test the ability of different dilutions of the aqueous extracts prepared from the finely ground powders of different plant species to inhibit the in vitro growth of $\mathrm{Cmm}$, a paper disc diffusion method was used (Bauer et al. 1966). For this purpose, a bacterial lawn was prepared by pouring $100 \mu$ of bacterial suspension $\left(10^{8} \mathrm{cfu} / \mathrm{ml}\right)$ and spreading it uniformly on the surface of nutrient agar (NA) plates. Sterilized paper discs $(6 \mathrm{~mm})$ were moistened with $20 \mu \mathrm{l}$ of each plant extract dilution and air dried. Negative control paper discs were moistened with $20 \mu \mathrm{l}$ of SDW and positive control paper discs with $20 \mu \mathrm{l}$ of Terramycin $(200 \mathrm{ppm})$. Each NA plate received 5 paper discs; three discs for the three dilutions, one disc for negative and one for positive control. The plates were incubated at $28^{\circ} \mathrm{C} \pm 2$ for $24 \mathrm{~h}$ and the resulting inhibition zones were measured across the discs with transparent plastic ruler. The experiment was repeated two times using five replications arranged in completely randomized design. The results obtained were analyzed in comparison with the standard antibiotic and the first five most effective plant extracts were selected for in vivo study.

\section{Detection of Secondary Metabolites in Aqueous Extracts of Plants}

The aqueous extracts $(10 \% \mathrm{w} / \mathrm{v}$, prepared as described before) of those plants that performed better in in vitro growth inhibition tests against $\mathrm{Cmm}$, were tested for the presence of major anti-bacterial plant secondary metabolites in them. To detect alkaloids, $1.5 \mathrm{ml}$ of $1 \% \mathrm{HCl}$ was mixed with $2 \mathrm{ml}$ of aqueous extract. The mixture was heated in water bath for a few minutes and then 6 drops of Mayer's reagent were added to it. The appearance of orange-colored precipitate indicated the presence of alkaloids (Rasool et al. 2010). For the detection of flavonoids, a few drops of lead acetate and $2 \mathrm{ml}$ of the plant aqueous extract were mixed together. Formation of yellow precipitate indicated the presence of flavonoids (Salhan et al. 2011). For the existence of tannins and saponins in the aqueous extract of the plants, the protocol of Saidulu et al. (2014) was followed. Briefly, a few drops of ferric chloride were mixed with $5 \mathrm{ml}$ of aqueous extract; the appearance of black precipitate was considered 
to be indicative of tannin. Saponin was detected by adding $2 \mathrm{ml}$ of the plant extract to $5 \mathrm{ml}$ of distilled water, agitating the mixture for $3 \mathrm{~min}$, resulting in persistent frothing. To show the presence of glycosides in the plant aqueous extracts, protocol of Sachin et al. (2011) was followed.

\section{In Vivo Studies}

Based upon in vitro results, five plants/weeds viz $P$. harmala, W. somnifera, M. azedarach, $C$. procera, and $M$. piperita were selected for further evaluation. Pot experiments were conducted in screen house to test the efficiency of different doses (i.e., 10, 20, 30 and $40 \mathrm{~g} \mathrm{~kg}^{-1}$ of dry potted soil) of finely ground dried powders of the selected medicinal plants on the control of tomato canker. Twenty five-days old tomato transplants (cv Rio Grande) were transplanted to $15 \mathrm{~cm}$-diameter earthen pots containing two $\mathrm{kg}$ steam-sterilized $\left(100^{\circ} \mathrm{C}\right.$ for $\left.6 \mathrm{~h}\right)$ soil pre-mixed with the different doses of plant powder (Ramesh et al. 2009). For plant inoculation, bacteria suspension was prepared as mentioned before. Five days post-transplantation, all plants were inoculated by clipping the lowest leaf with scissor dipped in bacterial suspension as well as spraying plants with the bacterial suspension (Rashmi et al. 2012). For comparison, standard antibiotic terramycin (100 ppm) was used (sprayed 4 times at two-week's interval, on inoculated plants) as a positive control. Inoculated potted plants without antibiotic or plant extract powder acted as negative control. The experiment was performed using completely randomized design (CRD) with five replications. The potted plants were watered as needed. The experiment was terminated 90 days after transplanting and data were recorded on disease severity, and yield-related parameters such as plant height $(\mathrm{cm})$, weight of fresh plant $(\mathrm{g})$, number of shoots plant $^{-1}$, tomato yield plant ${ }^{-1}(\mathrm{~g})$, root weight $(\mathrm{g})$, and dry plant weight $(\mathrm{g})$.

\section{Disease Severity (\%) and Data Analysis}

The five-category disease rating scale of Wai et al. (2013), with slight modifications (Din et al. 2016) was used for recording disease severity data. Using the equation, DS\% $=100 \sum n / 4 N$ (Bdliya and Dahiru 2006), the disease severity $(\%)$ for each treatment was then computed (DS\% $=$ disease severity $(\%), \sum n=$ sum of all ratings of the scale, 4 is the highest category on the rating scale and $N=$ sample size). Severity data were recorded four times for each treatment at two weeks interval.

Data recorded for plant growth characters such as plant height, root length, plant fresh and dry weights etc., and yield were considered as dependent variable. Treatments such as different medicinal plant extracts and their doses were considered as independent variables. The data recorded on different parameters were subjected to analysis of variance, using Statistix (Campbell and Madden 1990). To differentiate treatment means of different dependent variables, Fisher's protected least significance difference (LSD) test at $p=0.05$ was used (Gomez and Gomez 1984).

\section{Results}

\section{Morphology and Pathogenicity of C. michiganensis Subsp. michiganensis}

To verify that the preserved culture was pure and fully pathogenic, its morphological characteristics were checked by growing the bacterium on nutrient agar (NA) for $48 \mathrm{~h}$ at $28^{\circ} \mathrm{C}$ and its pathogenicity was confirmed by inoculating it to one-month-old tomato seedlings. The pathogen produced convex, mucoid and yellow colonies on the medium.

Table 1 Effect of aqueous extracts of some medicinal plant species on the in vitro growth inhibition of Clavibacter michiganensis subsp. michiganensis, $24 \mathrm{~h}$ after incubation at $30^{\circ} \mathrm{C}$

\begin{tabular}{|c|c|c|c|}
\hline $\begin{array}{l}\text { Medicinal } \\
\text { plants }\end{array}$ & $\begin{array}{l}\text { Concentration } \\
(\%)\end{array}$ & $\begin{array}{l}\text { Zones of inhibi- } \\
\text { tion }(\mathrm{mm})\end{array}$ & $\begin{array}{l}\% \text { decrease } \\
\text { over Ter- } \\
\text { ramycin }\end{array}$ \\
\hline \multirow{3}{*}{$\begin{array}{l}\text { Melia } \\
\text { azedarach }\end{array}$} & 100 & $12.00 \mathrm{~cd}$ & 48.58 \\
\hline & 75 & $10.80 \mathrm{defg}$ & 43.72 \\
\hline & 50 & 8.80 hijk & 35.40 \\
\hline \multirow{3}{*}{$\begin{array}{l}\text { Peganum } \\
\text { harmala }\end{array}$} & 100 & $14.40 \mathrm{~b}$ & 58.30 \\
\hline & 75 & $13.00 \mathrm{bc}$ & 52.63 \\
\hline & 50 & 10.00 fghi & 40.48 \\
\hline \multirow{3}{*}{$\begin{array}{l}\text { Nerium } \\
\text { oleander }\end{array}$} & 100 & 9.40 ghijk & 38.06 \\
\hline & 75 & $8.40 \mathrm{jk}$ & 34.00 \\
\hline & 50 & 6.401 & 25.91 \\
\hline \multirow{3}{*}{$\begin{array}{l}\text { Calotropis } \\
\text { procera }\end{array}$} & 100 & $11.40 \mathrm{def}$ & 46.15 \\
\hline & 75 & 9.80 ghij & 39.68 \\
\hline & 50 & $8.60 \mathrm{ijk}$ & 34.82 \\
\hline \multirow{3}{*}{$\begin{array}{l}\text { Allium } \\
\text { sativum }\end{array}$} & 100 & 9.20 hijk & 37.25 \\
\hline & 75 & $8.40 \mathrm{jk}$ & 34.00 \\
\hline & 50 & $8.00 \mathrm{k}$ & 32.39 \\
\hline \multirow{3}{*}{$\begin{array}{l}\text { Withania } \\
\text { somnifera }\end{array}$} & 100 & $11.800 \mathrm{~cd}$ & 47.77 \\
\hline & 75 & $10.20 \mathrm{efgh}$ & 41.30 \\
\hline & 50 & $9.00 \mathrm{hijk}$ & 36.44 \\
\hline \multirow{3}{*}{$\begin{array}{l}\text { Mentha } \\
\text { piperita }\end{array}$} & 100 & $13.00 \mathrm{bc}$ & 52.64 \\
\hline & 75 & $11.60 \mathrm{cde}$ & 46.96 \\
\hline & 50 & 9.40 ghijk & 38.06 \\
\hline $\begin{array}{l}\text { Control } \\
\text { (water) }\end{array}$ & N/A & $0.00 \mathrm{n}$ & N/A \\
\hline Terramycin & $200 \mathrm{ppm}$ & $24.70 \mathrm{a}$ & N/A \\
\hline LSD & N/A & 1.49 & N/A \\
\hline
\end{tabular}

Means with different letters within a column are significantly $(p \leq 0.05)$ different. Each value is a mean of five replicates. The experiment was repeated twice with similar results 
Fig. 1 In vitro growth inhibition zones (mm) of Clavibacter michiganensis subsp. michiganensis produced by aqueous extracts of $P$. harmela (a), and $M$. piperita (b), using paper disc method. $1=$ Terramycin, $2=100 \%, 3=75 \%, 4=50 \%$ and $5=$ sterilized distilled water


The inoculated tomato seedlings produced disease symptoms 10 days after inoculation. Initial symptoms appeared on lower leaves; later the stem showed splitting and wilting symptoms. Wilting symptoms on one side of seedlings indicated xylem infection. The bacterium was re-isolated from the infected plant samples to confirm Koch postulates.

\section{In Vitro Antibacterial Assay of the Phytoextracts}

Aqueous extracts $(100 \%, 75 \%$, and $50 \%$ concentrated) of $P$. harmala, M. piperita, A. sativum, W. somnifera, $M$. azedarach, $C$. procera and $N$. oleander decreased the in vitro growth of $\mathrm{Cmm}$. Among the different plants tested, the undiluted water extract of $P$. harmala showed the maximum anti-bacterial activity by producing $14.40 \mathrm{~mm}$ zone of inhibition (ZI) followed by that of M. piperita $(13.00 \mathrm{~mm}$ ZI), and $75 \%$ concentrated extract of $P$. harmala $(13.00 \mathrm{~mm}$ ZI), (Table 1, Fig. 1). The anti-bacterial activities of the undiluted aqueous extracts of M. azedarach $(12.00 \mathrm{~mm} \mathrm{ZI})$ and $W$. somnifera $(11.80 \mathrm{~mm} \mathrm{ZI)}$ were at par with each other. Surprisingly, A. sativum exhibited the minimum antibacterial activity $(9.20 \mathrm{~mm} \mathrm{ZI)}$ which was at par with that of $N$. oleander $(9.40 \mathrm{~mm} \mathrm{ZI)}$. The positive control, terramycin $(200 \mathrm{ppm})$, exhibited the highest antibacterial activity $(24.70 \mathrm{~mm} \mathrm{ZI)}$ while negative control produced no ZI. In comparison with the standard antibiotic, terramycin
(200 ppm), the undiluted water extracts of $P$. harmala and M. piperita were $58.30 \%$ and $52.64 \%$, respectively, as effective as the antibiotic.

\section{Detection of Plant Secondary Metabolites in Their Aqueous Extracts}

To determine if the presence or absence of a certain secondary metabolite in the aqueous extract of a plant was correlated to its ability to inhabit the in vitro growth of $\mathrm{Cmm}$, the aqueous extracts of the selected plants ( $P$. harmala, $M$. piperita, $W$. somnifera, $M$. azedarach and $C$. procera) were analyzed for the presence of major plant metabolites such as alkaloids, tannins, saponins, flavonoids and glycosides. The results revealed that the aqueous extracts of all plants had moderate amounts of alkaloids, tannins, saponins, flavonoids, and glycosides (Table 2). However, the extracts of some plants were found to have higher amounts of some metabolites. For example, P. harmala had more alkaloids and saponins than the other plants. Likewise, M. piperita had more alkaloids and tannins.
Table 2 Detection of common secondary metabolites in aqueous extracts of medicinal plant species

\begin{tabular}{llllll}
\hline Plant aqueous extracts & \multicolumn{5}{l}{ Secondary metabolites } \\
\cline { 2 - 6 } & Alkaloids & Tannins & Saponins & Flavonoids & Glycosides \\
\hline Peganum harmala & ++ & + & ++ & + & + \\
Mentha piperita & ++ & ++ & + & + & + \\
Withania somnifera & + & + & + & + & + \\
Melia azedarach & + & + & + & + & + \\
Calotropis procera & + & + & + & + & + \\
\hline
\end{tabular}

+ Moderate, ++ High. The experiment was repeated once with similar results 
Table 3 Effect of dried powders of medicinal plants on severity (\%) of bacterial canker of tomato 15-, 30-, 45- and 60-days post-inoculation

\begin{tabular}{|c|c|c|c|c|c|}
\hline Medicinal plants & $\begin{array}{l}\text { Doses } \\
\left(\mathrm{g} \mathrm{kg}^{-1} \text { soil }\right)\end{array}$ & $\begin{array}{l}14 \text { days post-inocula- } \\
\text { tion }\end{array}$ & $\begin{array}{l}28 \text { days post-inocula- } \\
\text { tion }\end{array}$ & $\begin{array}{l}42 \text { days post-inocula- } \\
\text { tion }\end{array}$ & $\begin{array}{l}56 \text { days post-inocula- } \\
\text { tion }\end{array}$ \\
\hline \multirow{4}{*}{$\begin{array}{l}\text { Peganum } \\
\text { harmala }\end{array}$} & 10 & $26.53 \mathrm{hi}$ & $33.23 \mathrm{fg}$ & $35.13 \mathrm{gh}$ & $39.00 \mathrm{~g}$ \\
\hline & 20 & $21.73 \mathrm{ijk}$ & $22.73 \mathrm{j}$ & 23.901 & $24.73 \mathrm{i}$ \\
\hline & 30 & $18.101 \mathrm{~m}$ & 13.661 & $12.70 \mathrm{o}$ & $11.76 \mathrm{kl}$ \\
\hline & 40 & $13.13 \mathrm{~m}$ & 12.631 & $11.30 p$ & 10.331 \\
\hline \multirow[t]{4}{*}{ Mentha piperita } & 10 & $30.13 \mathrm{efg}$ & $32.26 \mathrm{~g}$ & $37.66 \mathrm{fg}$ & $45.96 \mathrm{e}$ \\
\hline & 20 & 25.40 ghij & $26.53 \mathrm{i}$ & $27.43 \mathrm{jk}$ & $28.56 \mathrm{~h}$ \\
\hline & 30 & $20.26 \mathrm{jkl}$ & $17.03 \mathrm{k}$ & $15.66 n$ & $13.83 \mathrm{k}$ \\
\hline & 40 & $18.031 \mathrm{~lm}$ & 13.861 & 12.23 op & $11.40 \mathrm{kl}$ \\
\hline \multirow[t]{4}{*}{ Melia azedarach } & 10 & $34.80 \mathrm{cde}$ & $38.33 \mathrm{de}$ & $40.83 \mathrm{e}$ & $48.86 \mathrm{de}$ \\
\hline & 20 & $32.10 \mathrm{def}$ & $33.00 \mathrm{~g}$ & $35.00 \mathrm{~h}$ & $38.83 \mathrm{~g}$ \\
\hline & 30 & $29.13 \mathrm{fgh}$ & $28.23 \mathrm{hi}$ & $25.93 \mathrm{kl}$ & $25.16 \mathrm{i}$ \\
\hline & 40 & 24.76 ghij & $19.40 \mathrm{k}$ & $18.50 \mathrm{~m}$ & $19.30 \mathrm{j}$ \\
\hline \multirow{4}{*}{$\begin{array}{l}\text { Calotropis } \\
\text { procera }\end{array}$} & 10 & $38.56 b c$ & $42.86 \mathrm{c}$ & $49.26 \mathrm{c}$ & $54.26 \mathrm{c}$ \\
\hline & 20 & $36.33 \mathrm{~cd}$ & $36.16 \mathrm{ef}$ & $41.36 \mathrm{e}$ & $46.46 \mathrm{e}$ \\
\hline & 30 & $32.46 \mathrm{def}$ & $33.40 \mathrm{fg}$ & $39.90 \mathrm{ef}$ & $42.56 \mathrm{f}$ \\
\hline & 40 & $22.26 \mathrm{ijk}$ & $27.96 \mathrm{i}$ & $25.40 \mathrm{kl}$ & $24.13 \mathrm{i}$ \\
\hline \multirow{4}{*}{$\begin{array}{l}\text { Withania } \\
\text { somnifera }\end{array}$} & 10 & $43.767 b$ & $54.50 \mathrm{~b}$ & $62.66 \mathrm{~b}$ & $64.30 \mathrm{~b}$ \\
\hline & 20 & $39.13 b c$ & $39.80 \mathrm{~cd}$ & $51.73 \mathrm{c}$ & $55.00 \mathrm{c}$ \\
\hline & 30 & $36.00 \mathrm{~cd}$ & $37.30 \mathrm{de}$ & $44.86 \mathrm{~d}$ & $50.10 \mathrm{~d}$ \\
\hline & 40 & $33.70 \mathrm{cdef}$ & $31.10 \mathrm{gh}$ & $32.36 \mathrm{i}$ & $29.63 \mathrm{~h}$ \\
\hline Terramycin & $200 \mathrm{ppm}$ & $3.33 n$ & $1.00 \mathrm{~m}$ & $0.00 \mathrm{q}$ & $0.00 \mathrm{n}$ \\
\hline $\begin{array}{l}\text { Inoculated con- } \\
\text { trol }\end{array}$ & N/A & $61.333 \mathrm{a}$ & $66.40 \mathrm{a}$ & $76.80 a$ & $85.36 \mathrm{a}$ \\
\hline LSD value & N/A & 5.52 & 3.11 & 2.59 & 3.37 \\
\hline
\end{tabular}

Means with different letters within a column are significantly $(p \leq 0.05)$ different. Each value is a mean of five replicates. The experiment was repeated once with similar results

\section{In Vivo Studies}

\section{Effect of Medicinal Plant's Powder on Disease Severity}

To find out whether the in vitro anti-bacterial activity of the medicinal plants could hold true under in vivo conditions, four doses $\left(10,20,30\right.$ and $40 \mathrm{~g} \mathrm{~kg}^{-1}$ of soil) of the dried powder of each plant species (except A. sativum and N. oleander whose aqueous extract exhibited very little in vitro activity) were tested for the control of bacterial canker of tomato. In comparison to un-treated control plants, all four doses of the dried powders of the five medicinal plants tested significantly $(p<0.05)$ reduced disease severity at 14-, 28-, 42-, and 56-days post-inoculation (Table 3). In comparison to Teramycin (200 ppm)-treated plants at 56days post-inoculation, however, only those plants treated with the higher doses $\left(40 \mathrm{~g} \mathrm{~kg}^{-1}\right.$ soil and $30 \mathrm{~g} \mathrm{~kg}^{-1}$ soil $)$ of $P$. harmela and M. piperita performed better. Plants treated with $40 \mathrm{~g} \mathrm{~kg}^{-1}$ soil of the dried powders of P. harmela and M. piperita at 56 -days post-inoculation had $10.33 \%$ and $11.40 \%$, respectively, more disease severity than the plants treated with teramycin $(200 \mathrm{ppm})$. The disease severity levels of plants treated with $40 \mathrm{~g} \mathrm{~kg}^{-1}$ soil of M. piperita, $30 \mathrm{~g}$ $\mathrm{kg}^{-1}$ soil of M. piperita and $30 \mathrm{~g} \mathrm{~kg}^{-1}$ soil of $P$. harmela were statistically at par with each other.

\section{Effect of Medicinal Plant's Powder on Yield and Growth Parameters of Tomato}

The general trend of the effect of dried powders of the medicinal plants tested on tomato yield and plant growth characters was almost similar to that observed in case of disease severity. All doses of the dried powders of all tested plants (except $20 \mathrm{~g} \mathrm{~kg}^{-1}$ soil of W. somnifera for yield, $10 \mathrm{~g}$ $\mathrm{kg}^{-1}$ soil of $W$. somnifera for yield and plant height, and $10 \mathrm{~g} \mathrm{~kg}^{-1}$ soil of $C$. procera for plant height) significantly $(p<0.05)$ enhanced yield, fresh and dry weights per plant and plant height as compared to untreated inoculated control plants (Table 4). The higher dose $\left(40 \mathrm{~g} \mathrm{~kg}^{-1}\right.$ soil) of the dried powder of $P$. harmela enhanced dry weight, fresh weight, yield, and height per plant by $75.37 \%, 75.70 \%$, $73.11 \%$, and $92.57 \%$, respectively, of the antibiotic, terramycin (200 ppm). This was followed by the higher dose (40 $\mathrm{g} \mathrm{kg}^{-1}$ soil) of M. piperita. The corresponding per plant enhancements in dry weight, fresh weight, yield, and height 
Table 4 Effect of dried powders of medicinal plants on yield and other plant growth parameters of tomato plants inoculated with Clavibacter michiganensis subsp. michiganensis

\begin{tabular}{|c|c|c|c|c|c|}
\hline Medicinal plants & $\begin{array}{l}\text { Doses } \\
\mathrm{g} \mathrm{kg}^{-1} \text { soil }\end{array}$ & Dry weight (g) & Fresh weight (g) & Yield $(\mathrm{g})$ & Height $(\mathrm{cm})$ \\
\hline \multirow[t]{4}{*}{ Peganum harmala } & 10 & $37.96 j$ & 124.001 & $251.53 \mathrm{ijk}$ & 61.50 hijk \\
\hline & 20 & $44.93 \mathrm{~h}$ & $149.00 \mathrm{~h}$ & $352.10 \mathrm{efg}$ & 82.83 bcde \\
\hline & 30 & $61.56 \mathrm{~d}$ & $185.43 \mathrm{e}$ & $418.27 \mathrm{~cd}$ & $93.16 \mathrm{abc}$ \\
\hline & 40 & $67.10 \mathrm{c}$ & $201.53 \mathrm{c}$ & $452.47 \mathrm{c}$ & $96.00 \mathrm{a}$ \\
\hline \multirow[t]{4}{*}{ Mentha piperita } & 10 & $34.00 \mathrm{k}$ & $101.73 n$ & $235.13 \mathrm{jk}$ & 61.00 hijk \\
\hline & 20 & $43.20 \mathrm{hi}$ & $132.00 \mathrm{k}$ & $318.20 \mathrm{gh}$ & 65.83 ghij \\
\hline & 30 & $53.90 \mathrm{ef}$ & $164.10 \mathrm{f}$ & $384.53 \mathrm{def}$ & $82.50 \mathrm{cde}$ \\
\hline & 40 & $65.90 \mathrm{c}$ & $196.57 \mathrm{~d}$ & $401.83 \mathrm{cde}$ & $95.16 \mathrm{ab}$ \\
\hline \multirow[t]{4}{*}{ Melia azedarach } & 10 & $30.161 \mathrm{~m}$ & $91.73 \mathrm{o}$ & $234.87 \mathrm{jk}$ & $53.93 \mathrm{jkl}$ \\
\hline & 20 & $38.43 \mathrm{j}$ & $114.10 \mathrm{~m}$ & $284.47 \mathrm{hij}$ & 65.00 ghij \\
\hline & 30 & $44.90 \mathrm{~h}$ & $136.77 \mathrm{j}$ & 301.10 ghi & $73.46 \mathrm{efgh}$ \\
\hline & 40 & $51.83 \mathrm{f}$ & $155.37 \mathrm{~g}$ & $334.47 \mathrm{fgh}$ & 83.16 bcde \\
\hline \multirow[t]{4}{*}{ Calotropis procera } & 10 & $28.10 \mathrm{~m}$ & $83.06 \mathrm{p}$ & $217.47 \mathrm{kl}$ & $49.33 \mathrm{klm}$ \\
\hline & 20 & $33.90 \mathrm{k}$ & $100.97 \mathrm{n}$ & $234.73 \mathrm{jk}$ & $56.33 \mathrm{ijkl}$ \\
\hline & 30 & $41.86 \mathrm{i}$ & 124.471 & $285.67 \mathrm{hij}$ & 66.66 fghi \\
\hline & 40 & $48.93 \mathrm{~g}$ & $145.90 \mathrm{hi}$ & $318.97 \mathrm{gh}$ & $78.83 \mathrm{def}$ \\
\hline \multirow[t]{4}{*}{ Withania somnifera } & 10 & $24.43 n$ & $71.46 \mathrm{q}$ & $167.97 \mathrm{~lm}$ & $48.001 \mathrm{~m}$ \\
\hline & 20 & 31.031 & $93.80 \mathrm{o}$ & $168.101 \mathrm{~m}$ & $51.33 \mathrm{kl}$ \\
\hline & 30 & $36.40 \mathrm{jk}$ & $111.33 \mathrm{~m}$ & $234.40 \mathrm{jk}$ & $58.43 \mathrm{ijkl}$ \\
\hline & 40 & $34.23 \mathrm{k}$ & $136.77 \mathrm{j}$ & $284.77 \mathrm{hij}$ & 66.30 fghij \\
\hline Terramycin & $200 \mathrm{ppm}$ & $89.03 \mathrm{a}$ & $266.23 \mathrm{a}$ & $618.87 \mathrm{a}$ & $103.70 \mathrm{a}$ \\
\hline Inoculated control & N/A & $16.93 \mathrm{o}$ & $50.66 \mathrm{r}$ & $153.50 \mathrm{~m}$ & $37.00 \mathrm{~m}$ \\
\hline LSD & N/A & 2.75 & 3.30 & 63.31 & 12.58 \\
\hline
\end{tabular}

Means with different letters within a column are significantly $(p \leq 0.05)$ different. Each value is a mean of five replicates. The experiment was repeated once with similar results

were $74.01 \%, 73.83 \%, 64.94 \%$ and $91.76 \%$, respectively, of those obtained by the antibiotic teramycin (200 ppm).

\section{Discussion}

Organic amendment of soil using different plants/weeds for the control of plant diseases is an active research domain. In addition to being environment friendly, plant products are effective against many plant pathogens, both soil-borne and phylloplane-borne. Different formulations such as dried powders, green manures (Naz et al. 2015a, 2015b), foliar sprays or soil drenches with aqueous extracts (Deberdt et al. 2012) have been reported to have successfully controlled different biotic diseases. This practice is expected to replace or reduce the amount of different chemicals used for the control of plant diseases, resulting in the reduction of environmental pollution and human health hazards. In our current soil organic amendment research, we explored the plant-disease control bioefficacy of some abundantly and free-of cost available plant species, which are well-known locally for their use as folk medicine. These plants included: (i) W. somnifera is a medium-sized Solanaceous shrub hav- ing bioactive plant substances. Organic extracts of leaves of this plant were found to have high antibacterial activity against some human's and plant's bacterial pathogens (Singariya et al. 2012). (ii) M. azedarach, a member of the family Meliaceae, is one of the most useful traditional medicinal plants (Biswas et al. 2002). Methanol extracts of its seeds, fruits, leaves as well as flowers are very effective against some plant bacterial pathogens (Viqar et al. 2008; Neycee et al. 2012). Leaves of M. azedarach were found to have all major plant secondary metabolites, i.e. alkaloids, saponins, tannins, phenols, glycosides, steroids and flavonoids (Fazil et al. 2012). (iii) P. harmala is an important medicinal plant which is used in global folk medicine (Sharaf et al. 1997; Jumaa 2005). It has good antibacterial and antifungal properties (Lala et al. 2004). (iv) C. procera is a salt tolerant, small compact, desert shrub which is well known for its traditional medicinal properties (Murti et al. 2010). (v) M. piperita is a perennial medicinal plant containing 0.5-4\% volatile oil (Dew and Evans 1984). Volatile oil, aqueous extracts as well as organic extracts of M. piperita have been reported (Saeed et al. 2006; Bupesh et al. 2007; Al-sum and Al-Arfaj 2013) to have good antibacterial properties. The presence of many of these bioac- 
tive plant substances was confirmed by our test results. Our tests, however, are not analytical and show only rough estimates of the substances under investigation.

Our in vitro results indicated that the aqueous extracts of P. harmela and M. piperita, M. azedarach, W. somnifera and $C$. procera were highly effective in inhibiting the growth of $\mathrm{Cmm}$, the causal agent of bacterial canker of tomato. These results suggest the presence of anti-microbial secondary metabolites in these plants. Our results are similar to those of Sarpeleh et al. (2009) and Amel et al. (2012). Sarpeleh et al. (2009) chopped fresh $P$. harmela into small pieces and buried the plant material into bacteria- and fungi-infested soil two-three months prior to plantation. They found that the buried plants or plant parts slowly released watersoluble anti-microbial substances which killed pathogens present in soil. Moreover, some of these water soluble substances were absorbed by plant roots resulting in killing of pathogens present inside host plant tissue. The use of finely ground dried powder of $P$. harmala, in case of our studies, confirms the good results for this species. Amel et al. (2012) found $P$. harmala to be effective even against antibiotic-resistant bacteria and some other microbes. Under in vitro studies, it effectively restricted the growth of Candida albicans and Lactobacillus. Four important alkaloids including harmine, marmaline, harmalol and peganin were found in $P$. harmela. Harmine has been reported to have strong antibacterial and antifungal activities (Amel et al. 2012). Using in vitro agar well diffusion assay, Bupesh et al. (2007) found that aqueous as well as organic extracts of $M$. piperita leaves had strong antibacterial activity against a range of pathogenic bacteria. Saeed et al. (2006) tested the antibacterial activity of $M$. piperita against eleven human pathogenic bacteria, using disc diffusion method. They reported that the essential of peppermint exhibited the highest activity $(11.78 \mathrm{~mm}$ mean ZI) followed by its juice $(10.41 \mathrm{~mm}$ mean ZI). Similarly, 1:1, 1:5, 1:10 and even 1:20 dilutions of aqueous extracts of Mentha species were found to be effective against six human pathogenic bacteria (Al-sum and Al-Arfaj 2013). Water extracts of M. azedarach have been reported to enhance the defense system of cucumber against Meloidogyne incognita (Cavoski et al. 2012). The researchers found that the activities of catalase and peroxidase enzymes involved in host $\mathrm{H}_{2} \mathrm{O}_{2}$ detoxification were reduced, suggesting enhanced defense system of the host plant. Soil organic amendment with dried powder of Withania somnifera and $W$. coagulan had a significant effect on improving plant growth characters in vivo, reducing bacterial load $\mathrm{g}^{-1}$ soil and affecting bacterial wilt disease severity by decreasing the AUDPC values (Khan et al. 2019a; Najeeb et al. 2019). Saponins and steroids were also reported to be present in significant amounts in leaves of W. somnifera (Panchal et al. 2016). Finely ground powder of $C$. procera, added to soil $\left(40 \mathrm{~g} \mathrm{~kg}^{-1}\right.$ soil) was found to be about $60 \%$ as effective as the antibiotic in reducing bacterial wilt (BW) severity and as effective as the antibiotic in enhancing yield and yield parameters (Din et al. 2016). The researchers concluded that the dried powder of this plant had the potential to become an effective component of the integrated disease management against BW of tomato.

Contrary to the results of some other researchers (Jeyaseelan et al. 2010; Al-Obaidi 2014), however, the aqueous of $A$. sativum and $N$. oleander, according to our findings, did not perform as good as those of the other plants that we tested. Jeyaseelan et al. (2010) reported that both, organic solvent-extracts and water extracts of A. sativum bulbs inhibited the growth of plant pathogenic bacteria such as Xanthomonas axonopodis and Ralstonia solanacearum under in vitro conditions. This difference in results might be explained on the basis of formulation of the medicinal plant used, type of the solvent used, concentration of the extract used, and different nature of the bacterial pathogens involved. For example, we used finely ground dried powder of garlic to prepare its aqueous extract, whereas the other researchers used fresh garlic bulbs for preparing water extracts. Fresh garlic bulbs have some volatile compounds which are not present in the stored dried powder. Similarly, ethyl acetate-extracts of garlic were found to be twice as effective as aqueous extracts against bacterial pathogens (Jeyaseelan et al. 2010) indicating more solubility of anti-microbial chemicals of garlic in organic solvents. Likewise, Al-Obedi (2014) found that the aqueous extract of $N$. oleander significantly reduced the in vitro growth of Staphylococcus aureus and Escherichia coli. As little concentrations as $25 \mathrm{mg} \mathrm{ml}^{-1}$ produced growth inhibition zones of $22 \mathrm{~mm}$ and $19 \mathrm{~mm}$, respectively, of the two bacteria. In this case, the difference in results might be due to different concentrations used and different nature of the pathogens.

The observed lower disease severity, enhanced yield and yield-contributing plant growth characters of the inoculated tomato plants treated with $40 \mathrm{~g} / \mathrm{kg}$ soil of $P$. harmela, M. piperita and the other medicinal plants could be based upon many factors. One possibility is the presence of various anti-microbial compounds in the finely ground dried powders of the medicinal plants added to soil. Our results indicated that all the major anti-microbial compounds (i.e., alkaloids, tannins, saponins, flavonoids, and glycosides) were present in the aqueous extracts prepared from dried powders of $P$. harmela, M. piperita, M. azedarach, W. somnifera and $C$. procera. These antimicrobial compounds have diverse mechanisms of action against pathogens. For example, alkaloids inhibit vital enzymes, such as topoisomerase. Others damage DNA by intercalating into it (Tanaka et al. 2006). Similarly, some tannins directly kill bacteria by damaging their cell membranes (Mainasara et al. 2012). Other tannins bind to bacterial adhesins, re- 
sulting in the prevention of bacterial attachment to host cells (Wang 2014). Steroidal saponins damage cell membrane by disabling its sterol component, resulting in the death of bacterial cell (Wang et al. 2000). The phenolic compounds, flavonoids, produced in response to pathogen's attack, coagulate bacterial proteins and enzymes of vital pathways (AlObaidi 2014). The anti-microbial action of these bioactive plant compounds is, however, dose- and pathogen-contact dependent (Regnault-Roger et al. 2005; Naz et al. 2015b; Khan et al. 2019b). In our studies, the doses and amounts in soil amended with plant powder are most likely much lower than when pure substances are considered. Furthermore, there is no true contact between the pathogen in the plant and these substances in soil; unless some of them are directly absorbed by plant roots and go inside plant tissue to kill the pathogen as reported by Sarpeleh et al. (2009).

The possible activation of innate defense mechanism(s) of plants by natural elicitor compounds present in the dried powders of the medicinal plants (Walters et al. 2005) is another major fascinating scenario responsible for the observed lower disease severity and enhancement of yield and yield-contributing factors of the treated plants. Some of the components of the activated plant defense include reactive oxygen species or ROS-mediated oxidative burst, strengthening of cell walls, synthesis of anti-microbial compounds, changes in the levels of defense-related enzymes and priming of host cells etc. (Daayf et al. 2000; Kuc 2006; Cavoski et al. 2012). A coffee-leaf extract formulation, when sprayed on plants, induced defense genes in tomato against the bacterial pathogen Xanthomonas vesicatoia (Medeiros et al. 2009). By soil drenching potato plants with aqueous extracts Hibiscus sabdariffa, Punica granatum and Eucalyptus globulus, Hassan et al. (2009) demonstrated the elicitation of systemic resistance in potato against BW. Pre-inoculation foliar application of leaf extracts of Datura metel induced systemic resistance in rice plants, as evident from the accumulation of pathogenesis-related proteins and other defense-related compounds, resulting in reduced incidence of sheath blight and bacterial blight disease of rice under greenhouse conditions (Kagale et al. 2004). Interestingly enough, Graham and Myers (2011) discovered that the application of SAR (systemic acquired resistance) activators in the form of soil drench was more effective and the effect was more prolonged than their foliar sprays to control citrus canker bacterium, a non-soilborne pathogen of citrus. The longevity of the activity of soil-applied SAR activators was attributed to their gradual release, uptake by the plant roots, and translocation to the actively growing shoots (Sur and Strok 2003; Graham and Myers 2011). Moreover, these researchers also concluded that soil-applied SAR inducers could deter the appearance of copper resistance in bacteria. Other researchers (Graham and Leite 2007; Francis et al. 2009) also recommended soil application of SAR inducers to control citrus canker.

Our in vivo results of the higher doses $(40 \mathrm{~g} / \mathrm{kg}$ soil) of the dried powders of $P$. hamela, and M. piperita are very encouraging. The finely ground powders of these plants added to soil proved to be about $80 \%$ as effective as the antibiotic in terms of reducing the disease severity, and $73 \%$ as effective as the antibiotic in enhancing yield and yieldcontributing plant growth characters. This suggests that the dried powders of these plants or their extracts could be used as an effective component of the integrated disease management against bacterial canker of tomato or possibly other plant diseases. Taking advantage of the small-scale agricultural systems prevalent in Pakistan, dried powders of these medicinal plants could be directly applied to the root-zones of tomato plants with practically no increase in the input costs. Additionally, these plants are evergreen, available in large amounts free of cost which make them an attractive disease control option. Moreover, infested seed-bed soils could be treated with dried powders or green manures of these plants to make them disease-free which in turn could be used to produce disease-free tomato transplants. Many anti-microbial plant's secondary metabolites are more soluble in organic solvents than in water (Al-Obaidi 2014). Further research is needed for the evaluation of different organic solvents for the extraction of these anti-microbial metabolites, elucidation of chemical structures in case of discovery of new compounds, and testing the disease-control properties of these natural compounds against other plant pathogens. Moreover, the disease-control ability of these medicinal plants could even be further enhanced. For example, more complete physical disruption of the plant tissue by producing and using very fine powders versus coarse powders; mulching of the powder on the surface of soil versus mixing in soil; addition of small amount of some chemical to the powders etc. Other possible future research could include the identification and purification of the possible SAR inducer(s) present in the dried powders of these plants.

Conflict of interest M. Siddique, N. Din, M. Ahmad, A. Ali, I. Naz, S.S. Alam and N. Ullah declare that they have no competing interests.

Open Access This article is licensed under a Creative Commons Attribution 4.0 International License, which permits use, sharing, adaptation, distribution and reproduction in any medium or format, as long as you give appropriate credit to the original author(s) and the source, provide a link to the Creative Commons licence, and indicate if changes were made. The images or other third party material in this article are included in the article's Creative Commons licence, unless indicated otherwise in a credit line to the material. If material is not included in the article's Creative Commons licence and your intended use is not permitted by statutory regulation or exceeds the permitted use, you will need to obtain permission directly from the copyright holder. To view a copy of this licence, visit http://creativecommons.org/licenses/by/4. $0 /$. 


\section{References}

Agrios GN (2005) Plant pathology, 5th edn. Elsiever, London, pp 647649

Al-Obaidi O (2014) Studes on antibacterial and anticancer activity of Nerium oleander extracts. Eur Chem Bull 3:259-262

Al-sum BA, Al-Arfaj A (2013) Antimicrobial activity of the aqueous extracts of mint plant. Sci J Clin Med 2(3):110-113

Amel B, Yahyia A, Belaidi A (2012) Assessment of the antibacterial activity of crude alkaloids extracted from seeds and roots of the plant Pegnum harmala L. J Nat Prod Plant Resour 2:568-573

Anonymous (2016) Agricultural statistics of Pakistan. Govt. of Pakistan, Statistics Division, Pakistan Bureau of Statistics, Islamabad

Bauer AW, Kirby WMM, Sherris JC, Turck M (1966) Antibiotic susceptibility testing by a standardized single disc method. Am J Clin Pathol 45:493-496

Bdliya BS, Dahiru B (2006) Efficacy of some plant extracts on the control potato tuber soft rot caused by Erwinia carotovora ssp. carotovora. J Pl Prot Res 46(3):285-294

Biswas K, Chattopadhyay I, Banerjee RK, Bandyopadhyay U (2002) Biological activities and medicinal properties of neem (Azadirachta indica). Curr Sci 82:1336-1345

Bokaeian M, Saeidi S (2015) Evaluation of antibacterial acticvity of leaf extracts of Withania somnifera against anti-biotic resistant Staphylococcus aureus. Zahedan. J Res Med Sci 17(7):29-32

Bose TK, Kabir J, Maity TK, Parthasarathy VA, Som MG (2004) Vegetable crops, 1st edn. Naya Prakash, Kolkatta, p 987

Bradbury JF (1986) Guide to plant pathogenic bacteria CAB International, Wallingfurd, UK.Citrus Congress, Middle-East, Tel Aviv, Israel. Cult Pract Dis Nematodes 2:787-793

Bupesh G, Amutha C, Nandagopal S, Ganeshumar A, Sureshkumar P, Murali KS (2007) Antibacterial activity of Mentha piperita L. (peppermint) form leaf extracts-a medicinal plant. Acta Agric Slovenica 89:73-79

Campbell CL, Madden LV (1990) Introduction to plant disease epidemiology. Wiley, New York

Cavoski I, Chami ZA, Bouzebboudja F, Sasanelli N, Simeone V, Mondelli D, Miano T, Sarais G, Ntalli NG, Caboni P (2012) Melia azedarach controls Meloidogyne incognita and triggers plant defense mechanisms on cucumber. Crop Prot 35:85-90

Cowan NM (1999) Plant products as antimicrobial agents. J Clin Microbiol 12(4):564-582

Daayf F, Ongena M, Boulanger R, El Hadrami I, Belanger RR (2000) Induction of phenolic compounds in two cultivars of cucumber by treatment of healthy and powdery mildew-infected plants with extracts of Reynoutria sachalinensis. J Chem Ecol 26:1579-1593

Davis MJ, Gillaspie AG, Vidaver AK, Harris RW (1984) Calvibacter; A new genus containing some phytopathogenic coryneform bacteria, including clavibacter xyli sub sp. xyli and Clavibacter michiganensis subsp. michiganensis in tomatoes. Phytopathology 81:1519-1523

Deberdt P, Perrin B, Coranson-Beaudu R, Duyck PF, Wicker E (2012) Effect of Allium fistulosum extract on Ralstonia solanacearum populations and tomato bacterial wilt. Plant Dis 96:687-692

Dew MJ, Evans JR (1984) Peepermint oil for the irritable bowel syndrome; a multi center trialm. Br J Clin Pract 38:394-395

Din N, Ahmad M, Siddique M, Ali A, Naz I, Ullah N, Ahmad F (2016) Phytobiocidal management of bacterial wilt of tomato caused by Ralstonia solanacearum (Smith) Yabuuchi. Span J Agric Res 14(3): 1006

Dutta B, Gitaitis R, Smith S, Langston D Jr. (2014) Interactions of seed-borne bacterial pathogens with host and non-host plants in relation to seed infestation and seedling transmission. PLoS ONE 9(6):e99215. https://doi.org/10.1371/journal.pone.0099215

Fazil MA, Rao AS, Ahemad SR, Ibrahim M (2012) Phytochemical studies and antioxidant activity of Melia azedarach Linn leaves by DPPH scavenging assay. Int J Pharm Appl 3:271-276
Francis MI, Redondo A, Burns K, Graham JH (2009) Soil application of imidacloprid and related SAR inducing compounds produces effective and persistant control of citrus canker. Eur J Plant Pathol 24:283-292

Frey MF, Mayers R (2010) Antibacterial activity of traditional medicinal plants used by Haudenosaunee peoples of New York state. BMC Complement Altern Med 10:64

Gleason ML, Gitaitis RD, Ricker MD (1993) Recent progress in understanding and controlling bacterial cancker of tomato in eastern North America. Plant Dis 77:1069-1076

Gomez KA, Gomez AA (1984) Statistical Procedures for Agricultural Research. Wiley, New York

Graham JH, Leite RP (2007) Soil-applied neonicotinoids for control of bacterial disease on young citrus trees. In: Proc. Int. Workshop PR-Proteins and induced resistance against pathogens and insects Doorn

Graham JH, Myers ME (2011) Soil application of SAR inducers imdacloprid, Thiamethoxam, and acibenzolar-S-Methyl for citrus canker control in young grape fruit trees. Plant Dis 95:725-728

Hassan MAE, Bereika MFF, Abo-Elnaga HIG, Sallam MA (2009) Direct antimicrobial activity and induction of systemic resistance in potato plants against bacterial wilt disease by plant extracts. Plant Pathol J 25:352-360

Hong JC, Momol MT, Ji P, Olson SM, Colee J, Jones JB (2011) Management of bacterial wilt in tomatoes with thymol and acibenzolar-S-methyl. Crop Prot 30:1340-1345

Jeyaseelan E, Pathmanathan M, Jeyadevan J (2010) Inhibitory effect of different solvent extracts of Vitex negundo L. and Allium sativum L. on phytopathogenic bacteria. Arch Appl Sci Res 2:325-331

Jumaa GM (2005) Peganum harmala production. Eur J Sci Res 11:6-12

Kagale S, Marimuthu T, Thayumanavan B, Nandakumar R, Samiyappan R (2004) Antimicrobial activity and induction of systemic resistance in rice by leaf extract of Datura metel against Rhizoctnia solani and Xanthomonas oryzae pv. Oryzae. Physiol Mol Plant Pathol 65:91-100

Khan RAA, Ahmad B, Ahmad M, Ali A, Naz I, Fahim M (2019a) Management of Ralstonia solanacearum (Smith) Yabuuchi wilt in tomato (Solanum lycopersicum L) with dried powder of the medicinal plant Withania somnifera (L) Dunal. PAKJBOT 51(1):297-306

Khan RAA, Ahmad M, Naz I, Najeeb S, Yanlin L, Alam SS (2019b) Sustainable management of bacterial wilt of tomato using dried powder of Xanthium strumarium L. J Plant Pathol. https://doi.org/ 10.1007/s42161-019-00451-y

Kleitman F, Isaac B, Annette B, Naim I, Yunis F, Guido S, Dan W, Laura C, Karl-Heinz G, Rudolf E, Shulamit M (2009) Characterization of a Clavibacter michiganensis subsp. michiganensis population in Israel. Eur J Plant Pathol 121:463-475

Kuc J (2006) What's old and what's new in concepts of induced systemic resistance in plants, and its application. In: Multigenic and induced systemic resistance in plants. Springer, Berlin Heidelberg, pp 9-20

Kumar S, Choudhary HS, Seniya C (2011) In-vitro antibacterial study of aqueous and ethanolic extracts of some selected medicinal plants. J Chem Pharm Res 3:854-860

Lala S, Pramanick S, Mukhopadhyay S, Bandyopadhyay S, Basu MK (2004) Harmine: evaluation of its antileishmanial properties in various vesicular delivery systems. J Drug Target 12(3):165-175

Mainasara MM, Aliero B, Aliero AA, Yakubu M (2012) Phytochemical and Antibacterial properties of root and leaf extracts of Calotropis procera. Nigerian Journal of Basic and Applied Science 20(1): 1-6

Medeiros FCL, Resende MLV, Medeiros FHV, Zhang HM, Pare PW (2009) Defense gene expression induced by a coffee-leaf extract formulation in tomato. Physiol Mol Plant Pathol 74:175-183 
Murti Y, Yogi B, Pathak D (2010) Pharmacognostic standardization of leaves of Calotropis procera (Ait.) R. Br. (Asclepiadaceae). Int J Ayurveda Res 1:14-17

Najeeb S, Ahmad M, Khan RAA, Naz I, Ali A, Alam SS (2019) Management of bacterial wilt in tomato using dried powder of Withania coagulan (L) Dunal. Aust Plant Pathol. https://doi.org/10. 1007/s13313-019-0618-8

Naz I, Saifullah, Palomares-Rius JE, Block V, Khan SM, Ali S, Baig A (2015a) Sustainable management of the southern root-knot nematode, Meloidogyne incognita (Kofoid and White) chitwood, by means of amendments of Fumaria parviflora. Int J Agric Biol 17:289-296

Naz I, Saifullah, Palomares-Rius JE, Khan SM, Ali S, Ahmad M, Ali A, Khan A (2015b) Control of Southern root-knot nematode Meloidegyne incognita (Kofoid and White) chitwood on tomato using green manure of Fumaria parviflora Lam (Fumariaceae). Crop Prot 67:581-587

Neycee GHA, Nematzadeh A, Dehsestani A, Alavi M (2012) Evaluation of antibacterial effects of chinaberry (Melia ozedarach) against gram-positive and gram-negative bacteria. Int $\mathbf{J}$ Agric Crop Sci 4(11):709-712

Oguike FN, Onubueze DPM, Ughachukwu P (2013) Evaluation of activities of Marigold extract on wound healing of Albino Wister Rat. J Dent Med Sci 8:67-70

Panchal PK, Sharma N, Singh K (2016) Antibacterial effects of aerial part of Withania somnifera with chloroform extract on Pathogenic strains. World J Pharm Pharm Sci 5(8):979-988

Pradhanang PM, Ji P, Momol MT, Olson SM, Mayfield JL, Jones JB (2005) Application of acibenzolar-S-methyl enhances host resistance in tomato against Ralstonia solanacearum. Plant Dis 89:989-993

Ramesh R, Joshi AA, Ghanekar MP (2009) Pseudomonades, major antagonistic endophytic bacteria to suppress bacterial wilt pathogen, Ralstonia solanacearum in the eggplant (Solanum melongena L.). World J Microbiol Biotechnol 25:47-55

Rashmi BA, Gopalakarashan C, Thippeswamy B (2012) An efficient inoculation method to screen tomato, brinjal and chilli entries for bacterial wilt resistance. Pest Manag Hortic Ecosyst 18:70-73

Rasool R, Ganai BA, Akbar S, Kamili AN, Masood A (2010) Phytochemical screening of Prunella vulgaris L. an important plant of Kashmir. Pak J Pharm Sci 23:399-402

Regnault-Roger C, Philogene BJR, Vincent C (2005) Biopesticides of plant origin. Lavoisier, Paris

Sachin K, Choudhary HS, Seniya C (2011) In-vitro antibacterial study of aqueous and methanolic extracts of some selected medicinal plants. J Chem Pharm Res 3:854-860

Saeed S, Naim A, Tariq P (2006) In-vitro antibacterial activity of peepermint. PAKJBOT 38(3):869-872

Saidulu C, Venkateshwar C, Gangadhar Rao S (2014) Preliminary phytochemical studies of medicinal plant drug, Withania somnifera linn. J Biolife 2:306-312
Salhan M, Kumar B, Tiwari P, Sharma P, Sandhar HK, Gautam M (2011) Comparative anthelmintic activity of aqueus and ethaolic leaf extract of Clitoria ternates. Int J Drug Dev Res 3:68-69

Sarpeleh A, Sharifi K, Sonbolkar A (2009) Evidence of antifungal activity of wild rue (Pegnum harmala L.) on phytopathogenic fungi. J Plant Dis Prot 116:208-213

Sharaf MA, el-Ansari A, Matlin SA, Saleh NA (1997) Four flavonoid glycosides from Peganum harmala. Phytochemistry 44:533-536

Shenge KC, Mabagala RB, Morensen CN (2010) Current status of bacterial canker and spot diseases of tomato growing regions of Tanzania. J Agric Ext Rural Dev 2:84-88

Singariya P, Mourya KK, Kumar P (2011) Antimicrobial activity of the crude extracts of Withania somnifera and Cenchrus setigerus invitro. Pharmacogn J 4(27):60-65

Singariya P, Kumar P, Mourya KK (2012) Extract of antibacterial activity of leaf extract of Withania somnifera. Int J Pharm Tech Res 4(3):1247-1253

Singh G, Kumar P (2014) Antibacterial activity of flavonoids of Withania somnifera L. Int J Green Pharm 8:114-118

Sur R, Strok A (2003) Uptake, translocation and metabolism of imidacloprid in plants. Bull Insectol 56:35-40

Tanaka JCA, Da Silva CC, De Oliveira AJB, Nakamura CV, Dias BP (2006) Antibacterial activity of indole alkaloids from Aspidosperma ramiflorum. Braz J Med Biol Res 39:387-391

Viqar KA, Khan AA, Shukla I (2008) In-vitro antibacterial potential of Melia azedarach crude leaf extracts against some human pathogenic bacterial strains. Ethnobot Leflet 12:439-445

Wai KPP, Lee J, Mo H, Kim B (2013) Sources of resistance to bacterial wilt and restorer-of-fertility genotype for cytoplasmic male sterility in Capsicum pepper. Hort Environ Biotechnol 54(3):266-271

Walters D, Walsh D, Newton A, Lyon G (2005) Induced resistance for plant disease control: Maximizing the efficacy of resistance elicitors. Phytopathology 95:1368-1373

Wang L (2014) The antibacterial effect of secondary compounds in plants. 50th Annual Southeastern Michigan Junior Science and Humanities Symposium, Wayne State University, Detroit, 6.03.-7.03., pp 1-28

Wang Y, McAllister TA, Yanke LJ, Cheeke PR (2000) Effect of steroidal saponin from Yucca schidigera extract on ruminal microbes. J Appl Microbiol 88:887-896

Xiulan X, Sally A, Fulya GB, Karl-Heinz G, Rudolf E, Gireesh R (2010) Bioluminescence Imaging of Clavibacter michiganensis subsp. michiganensis Infection of Tomato Seeds and Plants. Appl Environ Microbiol 76(12):3978-3988. https://doi.org/10.1128/ AEM.00493-10

Naseerud Din is a PhD scholar and lecturer at the University of Agriculture, Department of Plant Pathology. Peshawar, Khyber Pakhtunkhwa, Pakistan. 